ARTUR PERICLES LIMA MONTEIRO

\title{
Online anonymity in Brazil: identification and the dignity in wearing a mask
}

\author{
Master's dissertation \\ Supervisor: Professor Virgílio Afonso da Silva
}


ARTUR PERICLES LIMA MONTEIRO

\section{Online anonymity in Brazil: identification and the dignity in wearing a mask}

Dissertation submitted to the graduate program on law at the Faculty of Law of the University of São Paulo, in partial fulfilment of the requirements for the degree of master of science, in the field of concentration of constitutional law, under the supervision of Professor Virgílio Afonso da Silva.

Revised version (4.Dec.2017). The original version is archived with the Faculty of Law. 
Catalogação da Publicação

Serviço de Biblioteca e Documentação

Faculdade de Direito da Universidade de São Paulo

Monteiro, Artur Pericles Lima

Online anonymity in Brazil: identification and the dignity of wearing a mask / Artur Pericles Lima Monteiro ; orientador Virgílio Afonso da Silva -- São Paulo, 2017.

$144 \mathrm{pp}$.

Dissertação (Mestrado - Programa de Pós-Graduação em Direito do Estado) Faculdade de Direito, Universidade de São Paulo, 2017.

1. liberdade de expressão. 2. anonimato. 3. internet. 4. privacidade. I. Silva, Virgílio Afonso da, orient. II. Título. 


\section{ACKNOWLEDGMENTS}

I have been quite fortunate in the support I was offered in the process leading to this dissertation, and it is the least I can do to acknowledge it.

Professor Virgílio Afonso da Silva has been a key influence to me since the first day I had classes with him, as an LLB student, in 2009. His encouragement from those first days, his kind understanding and committed advice were crucial, not just in the research and writing of this dissertation, but in defining my strive for a professional career in academia. I have benefited a great deal from his guidance, and perhaps even more from the powerful example of scholarly commitment to research and teaching he sets for all of us. A towering figure, he is never hesitant in unreservedly engaging in debate with students and taking our ideas as seriously as he does for established faculty. I could not overstate the significance of this practical lesson, both as a model I hope to follow in my career and in refining our reasoning and argumentative skills. It has been a tremendous privilege to have worked in this dissertation under his supervision. I am indebted to him for all this, and also for pointing out the issue this dissertation addresses, in a moot court seminar arranged by the group on Law, Internet and Society (Núcleo de Direito, Internet e Sociedade - NDIS) at the Faculty of Law at the University of São Paulo, in 2013. I am sure my argument itself also owes a great deal to the manner he approached the question of anonymity in that seminar.

I would also be remiss not to acknowledge how NDIS, then co-run by Dennys Antonialli and Francisco Cruz, shaped my research interests. I was introduced to research on law and technology by NDIS in 2012, and I am very grateful for this, particularly to Dennys and Francisco. NDIS is a testament to the flourishing potential of student-led projects at the Faculty of Law. 
Leonardo Rosa and Luciana Reis were two vital influences, from my second year as an LLB student, when I had them as tutors in two legal theory courses. I have since abused their kindness and generosity, quite frankly, at numerous times. In a rather surprising turn of events, my pestering conduct somehow produced genuine friendship, which I have also found in Yuri Luz. I could not count how many times we discussed issues involved in my research and other related questions, particularly when we were at a summit in Minas Gerais. These discussions and the contributions they have offered me were, with no exaggeration, essential to this dissertation. I am also grateful to Raphaela Rocha for her encouraging and caring words.

Caio Gentil Ribeiro and Jacqueline Abreu were also very generous in discussing a very early draft of this dissertation. I have also debated many connecting questions with Jacqueline Abreu; I relish this ongoing conversation.

I would also like to thank the participants of the Constitution, Politics and Institutions group, particularly, Carolina Marinho, Josecleyton da Silva, Natália Pires, Rafael Bellem, Rafael Nunes, as well as professor Conrado Mendes, for profitable debate on research, which I hope to have benefited from in writing this dissertation.

I am grateful to Clarissa Gross for her remarks and criticism of an early draft of the basic ideas of the dissertation.

I was also fortunate to rely on my friends Paulo Saffioti, Marcos de Sá, Marcela Mattiuzzo, Pedro Wieck and Fabiana Pinho throughout this process.

Lastly, I thank Adriane Sanctis. I could not have written this dissertation without her, just as we write our life together. She's supported me in every step, in so many ways. I am lucky to have her by my side.

This revised version of the dissertation assimilates many observations and suggestions offered by members of the dissertation committee in the viva voce examination on October 6, 2017. I am grateful to professors Carlos 
Affonso Pereira de Souza, Juliano Souza de Albuquerque Maranhão, and Marcel Leonardi, for their considerate comments. 

To Waldemar Bezerra Lima and Maria José Bezerra Lima, in memoriam. 



\section{ABSTRACT}

Artur Pericles Lima Monteiro. Online anonymity in Brazil: identification and the dignity in wearing a mask. 2017. 144 pp. Master's degree Faculty of Law, University of São Paulo, São Paulo, 2017.

Anonymity has long been held in disrepute by Brazilian constitutional law literature, which typically assigns it no value. Prevailing scholars insist on an interpretation of the constitution which reads an identification requirement into the clause on anonymity. The internet presents a challenge for this understanding of freedom of expression. This dissertation addresses that challenge by adopting an interpretive approach. It starts by considering what the implementation of that reading of the constitution would look like in practice, exploring the strategies adopted by the Press Act of 1967. Calling into question, both for pragmatic and substantive reasons, whether those strategies would be available if applied as a general imposition on communication, the argument turns to other practices admitted by Brazilian law, or explicitly provided by the constitution, that are inconsistent with the reading of an unrestricted identification requirement. What the anonymity clause means is thus shown to turn on a question of value. We must consider that question in light of the best theory of the point of our constitutional rights, particularly freedom of expression. By adopting a constitutive justification, which connects it to democracy, to political legitimacy and, ultimately, to dignity, we appreciate that anonymity must be protected by freedom of expression just as any part the content of the speech would. Identification is expressive, and so is anonymity. The internet makes this patently clear by enabling anonymous personal communication, which creates the possibility of 'anonymous intimacy'. This approach of constitutive justification of freedom of expression also serves us well in our understanding of the right to privacy. It provides us with the best basis for why surveillance is wrong, even when it is successful. So conceived, the right to privacy insists that government must not interfere with the private lives of individuals in a manner which is inconsistent with dignity. Having rejected the identification paradigm, the dissertation then offers a reinterpretation of Brazilian law as regards online anonymity tools, anonymous platforms and anonymous content. 



\section{RESUMO}

Artur Pericles Lima Monteiro. Anonimato online no Brasil: identificação e a dignidade de usar uma máscara. 2017. 144 pp. Mestrado - Faculdade de Direito, Universidade de São Paulo, São Paulo, 2017.

$\mathrm{O}$ anonimato tem sido visto em descrédito pelo direito constitucional brasileiro, que não lhe atribui valor algum. Insiste-se numa interpretação da constituição que lê um dever de identificação no dispositivo sobre anonimato. A internet apresenta um desafio a esse entendimento. Esta dissertação responde a esse desafio a partir de uma abordagem interpretativa. Ela começa com uma análise de como essa leitura da constituição poderia ser colocada em prática, discutindo as estratégias adotadas pela Lei de Imprensa de 1967. Depois de colocar em xeque por razões tanto pragmáticas quanto substantivas - a noção de que tais estratégias poderiam ser adotadas para condicionar a comunicação em geral, a dissertação examina outras práticas, admitidas pelo direito brasileiro ou expressamente contidas na constituição, que são inconsistentes com a leitura de um dever de identificação ilimitado. $\mathrm{O}$ significado do dispositivo sobre o anonimato, em consequência, só pode ser uma questão de valor. Essa questão é primeiramente considerada a partir da melhor teoria sobre o propósito da liberdade de expressão. Ao adotar uma justificação constitutiva da liberdade de expressão, que a conecta à democracia, à legitimidade política e, em última análise, à dignidade, nós compreendemos como o anonimato deve ser protegido pela liberdade de expressão da mesma maneira que qualquer parte do conteúdo da expressão. A identificação é expressiva, e o anonimato também. A internet torna isso patente com a expressão pessoal anônima, que cria a possibilidade de "intimidade anônima". Essa abordagem da justificação constitutiva da liberdade de expressão também é útil para a nossa compreensão do direito à privacidade. Ela nos fornece o melhor embasamento para a questão de o que há de errado com a vigilância, mesmo quando ela é bem sucedida. Assim concebido, o direito à privacidade demanda que o Estado não interfira com a vida privada dos indivíduos de uma maneira inconsistente com a sua dignidade. Rejeitando o paradigma da identificação, a dissertação apresenta uma nova interpretação do direito brasileiro em relação a ferramentas de anonimato online, plataformas anônimas e conteúdo anônimo 



\section{TABLE OF CONTENTS}

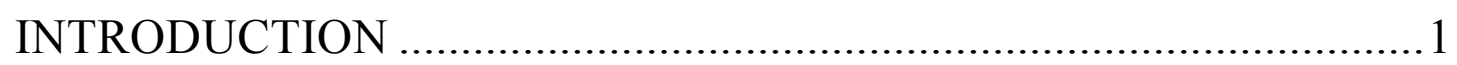

- The problem of digital anonymity in Brazil..................................... 1

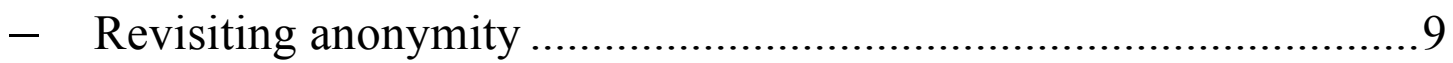

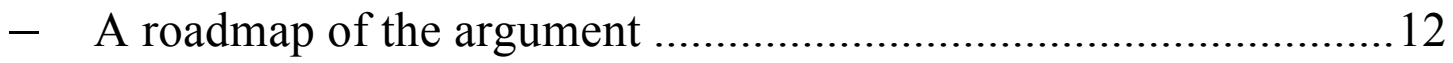

1. ANONYMITY AND THE IDENTIFICATION PARADIGM: THE

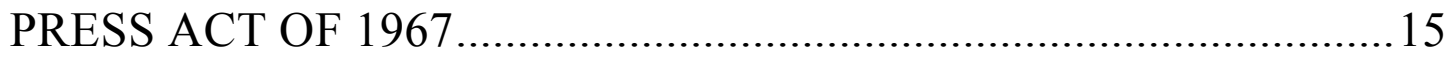

- The identification-requirement paradigm in the Press Act of 196716

2. REVISITING ANONYMITY: PRACTICES THAT DO NOT FIT THE IDENTIFICATION PARADIGM …........................................26

- Secret ballot and secrecy of jury deliberations ................................26

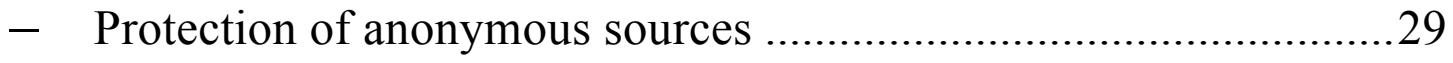

- Anonymous reporting of criminal activity .......................................32

- No unconditional identification requirement ...................................35

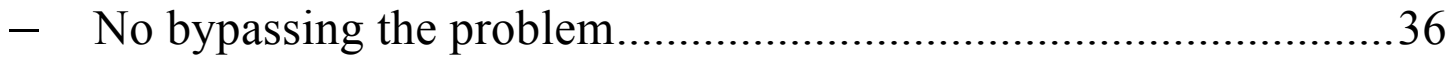

3. THREE THEORIES OF FREEDOM OF EXPRESSION: TRUTH, SELF-GOVERNMENT AND DIGNITY ............................................42

- Truth and the marketplace of ideas ...................................................43

- The Madisonian ideal and self-government......................................47

- Ronald Dworkin, democracy and dignity ......................................51

- Dignity and prior restraint: what is wrong with censorship? ..........60

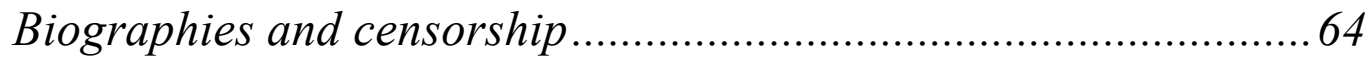

4. FREEDOM OF EXPRESSION AND ANONYMITY .....................70

- 'A shield from the tyranny of the majority' — US first amendment doctrine on anonymity ................................................................ 71

- Inspecting the value in anonymous speech ..................................74

- A genuine transformation enabled by the internet: anonymous

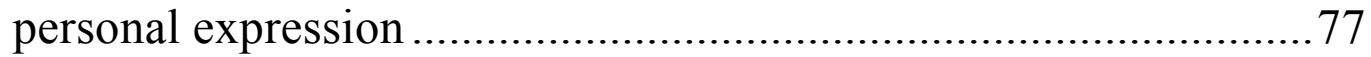

- Anonymity and identification as expressive ................................... 81 
- Does freedom of expression protect anonymous internet access? ..87

5. PRIVACY CONFRONTS THE IDENTIFICATION

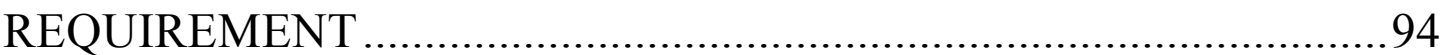

- A balance between privacy and surveillance? .................................99

- General warrants and privacy.......................................................97

- Dignity and surveillance: privacy and power.................................101

6. REINTERPRETING THE LAW ON ONLINE ANONYMITY AND

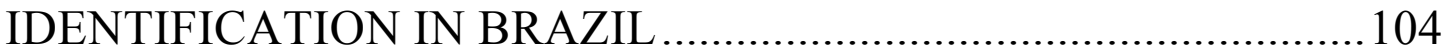

- Anonymity and identification online: reviewing the legal framework governing the internet in Brazil ................................. 107

- Online anonymity tools (and limits) ...........................................110

- Identification and anonymity under marco civil da internet.........114

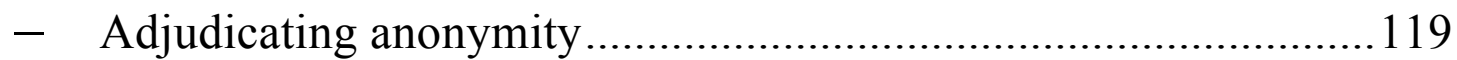

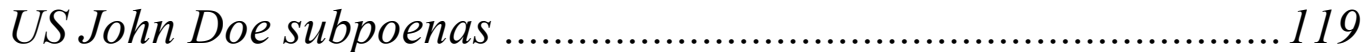

Revisiting the process Doe is due in Brazil................................. 121

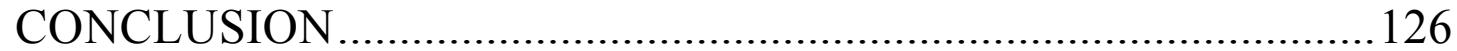

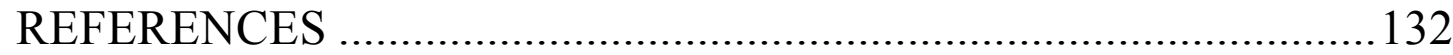






\section{INTRODUCTION}

\section{The problem of digital anonymity in Brazil}

Making sense of our values on the digital era often seems overwhelming. Technological changes transform the practical possibilities for the exercise of both individual autonomy and state power. Our established conceptions about liberty and democracy often appear to fall short of providing answers for the barrage of arising challenges.

Anonymity presents one such challenge. This is particularly true in Brazil, where the constitution includes specific language by which 'anonymity is forbidden' (art. 5, IV) ${ }^{1}$. This longstanding provision which I will refer as the anonymity clause -, restated in every constitution since Brazil abandoned monarchy (except for the one adopted by the latest authoritarian regime in 1967, and for its 1969 constitutional amendment which effectively enacted a new constitution), has been held as unproblematic by the prevailing literature. It is regarded by leading scholars as establishing what we might call an identification requirement, even though they might have failed to acknowledge this.

Supporters of the identification-requirement interpretation of the constitution gauge identification as the price demanded for the enjoyment

\footnotetext{
'Art. 5. Everyone is equal before the law, with no distinction whatsoever, guaranteeing to Brazilians and foreigners residing in the Country the inviolability of the rights to life, liberty, equality, security and property, on the following terms: [...] IV - manifestation of thought is free, but anonymity is forbidden', KEITH S. ROSENN, Constitution of the Federative Republic of Brazil: October 5, 1988 (as Amended to September 15, 2015), Oxford, 2015 (emphasis added).
} 
of freedom of expression. José Afonso da Silva, a leading constitutional scholar, is often quoted maintaining that:

Freedom of expression has its burdens, such as that one exercising it must assume responsibility for the resulting expressed ideas, in order that, should it be the case, one may be held liable for the damage caused onto others. ${ }^{2}$

This view is endorsed by other commentators ${ }^{3}$, who frequently associate anonymity with cowardice ${ }^{4}$. Thus, as per this reading of the anonymity clause of the constitution, all anonymous speech and all means enabling anonymous speech are proscribed: be it books, newspapers, magazines, radio broadcasting 5 , TV broadcasting, letters ${ }^{6}$ and posters ${ }^{7}$, and even 'internet messages, ${ }^{8}$.

Based on this understanding of the constitution, courts and lawmakers alike have at various times sought to curb anonymity on the internet. At congress, bills have been introduced that would require internet service providers (ISPs) to retain records of internet activity linked to a

2 José AfONSO DA SILVA, Art. $5^{\circ}$, IV , in Comentário contextual à Constituição, Malheiros, São Paulo, 2012, p. 92. 'A liberdade de manifestação do pensamento tem seus ônus, tal como o de o manifestante identificar-se, assumir claramente a autoria do produto do pensamento manifestado, para, sendo o caso, responder por eventuais danos a terceiros'.

3 'Free expression of thought is compensated by the prohibition of anonymity' ('A livre expressão do pensamento tem por contrapartida a proibição do anonimato'), MANOEL G. FERreIRA FILHO, Art. $5^{\circ}, \mathrm{IV}$, in Comentários à Constituição brasileira de 1988, Saraiva, São Paulo, 2000, p. 31; similarly JULIANA ABRUSIO, Os limites da liberdade de expressão na internet, in Educação digital, 2016, p. 120; José CRETELla NeTO, Art. $7^{\circ}$, in Comentários à lei de imprensa, Forense, Rio de Janeiro, 2008, pp. 76-78; ÊNIO S. ZuLIANI, Art. $7^{\circ}$, in Comentários à lei de imprensa, RT, São Paulo, 2007, pp. 158-159; DARCY A. MIRANDA, Art. $7^{\circ}$, in Comentários à lei de imprensa, RT, São Paulo, 1994, p. 110; UADI L. Bulos, Art. $5^{\circ}$, IV, in Comentários à Constituição Federal de 1988, São Paulo, 2014 ${ }^{11}$, p. 122.

${ }^{4}$ ÊNio S. ZUliani, Art. $7^{\circ}$, cit., p. 159; DarCy A. Miranda, Art. $7^{\circ}$, cit., p. 110.

5 Francisco C. PONTES DE MiRAnda, Liberdade de pensamento, in Comentários à Constituição de 1946, vol. 4, Rio de Janeiro, $1960^{3}$, pp. 434-5.

${ }^{6}$ AleXANDRE DE MoRAES, Liberdade de pensamento, in Constituição do Brasil interpretada e legislacão constitucional, Atlas, São Paulo, 2011, p. 130.

${ }^{7}$ Francisco C. PONTES DE MiRANDA, Liberdade de pensamento, cit., p. 435.

${ }^{8}$ AlexANDRe De MORAES, Constituição do Brasil interpretada e legislacão constitucional, Atlas, São Paulo, 2011, p. 130. 
government-issued ID. Mobile applications marketed as offering anonymity were the target of injunctions.

Bill no. 6.928/2017, introduced in February 2017 by representative Lieutenant Lúcio, would require ISPs and platforms alike to secure page content on the internet be signed using a government-regulated digital signature scheme. While that bill has since been withdraw, another legislative proposal would go further: bill no. 8.043/2017, introduced in July 2017 by congressman Ricardo Izar, would impose on ISPs a mandate of keeping the individual taxpayer number $(\mathrm{CPF})^{9}$ associated with users 'opening pages on internet applications'. A different bill, bill no. $7.224 / 2017$, proposed by representative Victor Mendes, would create a mandate for every website, blogs included, to ostensibly display information identifying those responsible for the website and for "the content" therein. Proponents of all bills cite the anonymity clause as direct basis for imposing those identification mandates.

A similar notion has been advanced at court. In August 2014, granting a request from a public prosecutor, a Brazilian judge in the state of Espírito Santo issued a preliminary injunction against Secret, a then-popular mobile application. Plaintiff had argued the app, which was marketed as a social network where users could post or comment without publicly disclosing their true identities, conflicted with Brazilian law. The court agreed: citing instances of defamation within the platform, it found the app to be illegally operating in Brazil, deriving its holding directly from the anonymity clause on constitution (art. 5, IV). Apple, Google and Microsoft (where the app was listed as Cryptic) were ordered to make the app unavailable on their official application repositories, and to remotely remove it from smartphones in which it had been installed ${ }^{10}$.

CPF stands for Cadastro de Pessoas Físicas, a national taxpayer database which in practice is necessary for everyday life in Brazil. It is akin to the Social Security Number in the United States and the National Insurance Number in the United Kingdom.

$10 \quad$ Case 0028553-98.2014.8.08.0024, $5^{\text {a }}$ Vara Cível de Vitória, Espírito Santo, judge Paulo César de Carvalho, decision of August 19th 2014. The ruling in Portuguese may be accessed through the court's website, inserting the case number at $<$ http://aplicativos.tjes.jus.br/consultaunificada/faces/pages/pesquisaSimplificada.xhtml $>$. I 
The argument against Secret, then, was straightforward: since the constitution requires any person intent on exercising her freedom of expression to be duly identified as the author of her ideas, any means failing such identification requirement should be quashed. Yet the implications flowing from this reading of the constitution are not confined to that applications - nor to other platforms trading on anonymous or pseudonymous social media, like Sarahah. As admitted by lawmakers proposing bills that would impose new mandates, the internet is itself an enabler of anonymity. Supporters of the identification requirement consequently see the web as in conflict with the Brazilian constitution.

Suppressing any platform that permits anonymity might actually entail a ban on internet in Brazil itself: its current technological architecture does not preclude non-identified connections ${ }^{11}$. Enforcing a ban on anonymity read as an identification requirement while avoiding a ban on the internet itself would, in turn, require drastic legal action for strict state policing of the web, through a real-name policy on connection and use (ie compelling registration with genuine identification before users are able to browse the web and post any content), the blocking of anonymity tools (such as

\footnotetext{
have also made it available here: <https://www.dropbox.com/s/q0ze1239w7jnp49/MPES\%20v\%20Secret\%20e\%20outros\%20-\%20decis\%C3\%A3o\%20liminar.pdf?dl=0>.

${ }^{11}$ LAWrenCe LeSSig, Code, Basic Books, New York, 2006², p. 35; A M. FroOMKIN, From anonymity to identification, «Journal of Self-Regulation and Regulation», 1 (2015), pp. 120-39 (arguing online anonymity is withering but still possible); BRUCE SCHNEIER, Anonymity and the internet, $(2010)<\mathrm{https} / / / \mathrm{www}$. schneier.com/blog/archives/2010/02/anonymity_and_t_3.html $>$, accessed 27.Aug.2017.
} 
Tor $^{12}$, anonymous VPNs ${ }^{13}$ and proxies ${ }^{14}$ ), and strict content filtering (as to prevent anonymous content generated outside of Brazilian jurisdiction).

These are radical measures that might be too costly, inefficient or simply unviable; such intense constraints would, in any case, fundamentally alter the operation of the internet in Brazil. Suppressing anonymity without any reservations, as suggested by prevailing Brazilian legal scholars, would effect a momentous threat to the protection of privacy. Lawrence Lessig notes the internet 'gives an individual a kind of power that doesn't exist in real space. This is not just the ability to put on a mask; it is the ability to hide absolutely who one is ${ }^{15}$. To the extent that this is true (as absolutely hiding who one is realistically unfeasible), we must not fail to

12 'Tor is an anonymity and censorship circumvention tool: it is a suite of software that uses anonymizing protocols designed to work over ordinary IPs. Tor nodes (computers running Tor networking software) build safe network circuits between the user seeking anonymity and the websites the user wants to access. Tor clients use intermediary systems called "relays," computers that run Tor software and configured to create these circuits for anyone who needs them' Peter Loshin, Practical anonymity: Hiding in plain sight online, Syngress, Waltham (MA), 2013, p. 5.

13 In simple terms, a virtual private network (VPN) that might be employed in the interest of anonymising internet connection is provided by a service that maintains no records of access, which would make it technically impossible to comply with a subpoena for specific subscriber information. A VPN in this sense is a network users remotely access on top of their internet connection and through which all internet traffic is directed. Cf. "VPN encrypts all of the packets sent out from client's PC and send it to VPN server through a tunnel called "Secure VPN Tunnel" which is established between the client's PC and the VPN server by the VPN software installed in client's PC. The strength of VPN lie in the fact that once the environment is established, all packets that are sent out from the client's PC are encrypted, regardless of the type of application they use. This way, even if ISP or hackers retrieve transferred packets, they will have difficulty of decrypting them in order to extract private information. The only way to decrypt those packets is to obtain the secret key from the VPN server' NGUYEN P. HOANG \& DAVAR PISHVA, Anonymous communication and its importance in social networking, (2016), p. 38.

14 '... a mechanism through which you can connect to a network, where the proxy system acts on your behalf. In other words, if you connect to a remote server through a proxy, the proxy connects to the Internet for you, and pretends to be you, for the purpose of connecting to that server - the server thinks that you are the proxy system, and doesn't know where you are actually connecting to the Internet from'. PeTER Loshin, Practical anonymity: Hiding in plain sight online, cit., p. 5.

${ }^{15}$ LAWRENCE LeSSIG, Reading the Constitution in cyberspace, «Emory Law Journal», 45 (1996), pp. 876-877. 
appreciate that an absolute denial of anonymity on the internet creates a situation that would simply be unfeasible otherwise.

On the context of the internet, positive identification is not equivalent to simply not wearing a mask. Rather, it would represent wearing a badge or a name tag at all times, and not just any, but one that conveys, aside from name and photo, the record of all actions and opinions of the person wearing it, organised in such a fashion as to enable swift searches by anyone who might be of passing interest.

While such bizarre contrafactual examples would perhaps be rejected even by the most radical opponents of anonymity in Brazilian legal literature, we must recognise such a scenario would be compatible with an account that regards anonymity as an evil which the law should work to eradicate.

The internet thus clearly warrants re-examining the issue of the legal treatment of anonymity, which is the subject of this dissertation. I mean to answer the question of what sense should we make of the anonymity clause in the Brazilian constitution in the face of the challenge the internet presents ${ }^{16}$.

16 Very little work is available on this topic. Mariana Cunha e Melo has examined the problem by employing a proportionality test (MARIANa C. E. Melo, The "Marco Civil da Internet" and its unresolved issues: free speech and due process of law, CRV, Curitiba, 2016.). She turns to the record of legislative debate of the Brazilian constitutional convention of 19878 , finding that 'the framers' intention was to identify the prohibition of anonymity with the protection of nor and reputation' (at 64-5). Her conclusion is thus that 'the Constitution does not ban anonymity to advance law enforcement interests not related to the protection of honor' (at 64). So whenever 'prohibiting anonymity would not foster the constitutional interests the rule was created to advance, anonymity should be not only permitted, but protected by the interpreter' (at 56). She offers important insight. Basing the constitutional interpretation on legislative intention, however, is hardly a persuasive strategy. At any rate, it does seem that the interpretation endorsed by Cunha e Melo fails to account for clear instances where a general right to anonymity could not be sensibly claimed, for reasons other than risks to personal reputation. Voting is an example: the ballot itself may be secret, but voters are required to identify before casting a ballot, and information concerning who voted is registered. Cunha e Melo's proposal, of a general right to anonymity except where reputation is implicated, does seem to fall prey to Scalia J's objections in McIntyre v Ohio Elections Comission 514 US 334, 381-3 (1995) (Scalia J, dissenting). While he does not provide analysis supporting it, Walter Capanema similarly argues for reading the anonymity clause so that 'the anonymity that the constitution forbids is only that which brings injury to others'. WALTER A. CAPANEMA, O direito 
The foremost issue in answering that involves determining whether the traditional identification-requirement reading of the constitution stands in the digital era. I hope to show that - while that might have been a serviceable interpretation as applied to written media - technological transformations brought about particularly by the internet evince how it is a fundamentally flawed understanding that fails to account for its entailed repercussions to the foundational values of a democratic society.

At this point someone could perhaps object that inspecting anonymity generally, instead of a particular case, would be more fruitful. Frank Easterbrook famously excoriated the study of 'the law of cyberspace', which he deemed as pointless as the study of 'the law of the horse ${ }^{17}$. Part of the ensuing argument, however, is that we must attend to the practical consequences of the interpretation of the anonymity clause, and the discussion will be decisively affected by the digital context.

Of course, we cannot hope to arrive any worthwhile conclusions regarding this question of constitutional interpretation if we lack a theory of what the constitution, constitutional rights, and democracy itself stand for. The argument will accordingly explore those broader aspects at some length, to the extent that it is required for the question we have set out to answer. Yet there is another manner those encompassing question will be present in the argument. The challenge technology presents to constitutional interpretation will, I expect, prove profitable beyond the question of digital anonymity ${ }^{18}$. I believe it will contribute to our more

ao anonimato: uma nova interpretação do art. $5^{\circ}, I V, C F$, in Jurisdição constitucional, democracia e direitos fundamentais, 2012, pp. 543-58. ('[...] propõe-se uma reinterpretação dessa norma [...] de modo a afirmar que o anonimato vedado pela Magna Carta é só aquele que cause prejuizos a terceiros', at 556.) Similar objections apply.

17 That is, although '[l]ots of cases deal with sales of horses; others [...] with people kicked by horses; still more [...] with the licensing and racing of horses, or with the care veterinarians give to horses, or with prizes at horse shows', '[t]eaching 100 percent of the cases on people kicked by horses will not convey the law of torts very well'. This point would be better served by studying the general rules of tort, which will govern any cases concerning horses, dogs, etc. Cyberspace and the law of the horse, «The University of Chicago Legal Forum» (1996), pp. 207-208.

18 While I use digital anonymity, online anonymity and anonymity on the internet interchangeably, distinctions could be drawn. Digital anonymity is an encompassing phrase, which could refer generally to all sorts of digital or electronic communications. Online 
general understanding of important issues of constitutional law, particularly to prevailing views of freedom of expression and the right to privacy in Brazil. In other words, as Lawrence Lessig contended in response to Easterbrook, I hope attending to the particular problem of digital of anonymity will 'illuminate the entire law',

anonymity and internet anonymity may be taken as synonymous, both designating anonymity in contexts on network communications. So, while digital anonymity would include the use of an offline device, online (or internet) anonymity would not. While it is possible this distinction (between digital and online anonymity) could be relevant in some contexts, this dissertation does not go into situations that would merit an explicit distinction throughout the text; the terms are used interchangeably. A further terminological distinction is yet subtler, while perhaps more contentious, that between internet anonymity and Internet anonymity. For a long time, the prevailing usage of the word insisted in capitalising internet as means of distinguishing the global internet, as a historical development resulting from the work on the ARPANET and NSFNET networks, and any generic, perhaps non-public internet, or network of networks. While we should not fail to appreciate the distinction, context is generally sufficient to make clear which internet is referred (for instance, 'the internet', with no qualifications, absent any special context, clearly must refer to the global internet). Lowercase internet further favours legibility. It does seem to me that the most important aspect in all this is the acknowledgement that the internet as we experience it today is not exclusively the product of the pioneering work (mainly) in the 1970s and 1980s, but rather something integral to everyday social life - and decisively shaped by social practices that have had their own development and that differ from the vision those pioneers had for it. Capitalising it, as we would a proper name, does seem to ignore this. This is not to say lowercase internet is less sensitive to the revolution brought about by the internet; it is actually the opposite: it has been so successful as to be absorbed as a common noun. Thomas Kent, then the standards editor of the Associated Press, defended its shift to lowercase by making the case the internet is perceived by some as something that has 'always been there', 'like water'. Bulletin! The "Internet" Is About to Get Smaller (2016) $<$ https://www.nytimes.com/2016/05/25/business/media/internet-to-be-lowercase-in-new-yorktimes-and-associated-press.html $>$ (emphasis added). ("Mr. Kent, of The A.P., said of the devotion to the capital I, "Some people feel sort of physically deep in their soul that it's a proper noun." "They would compare it to a physical place with a proper name. But I just don't think most people see it that way anymore," he added. "For younger people, it's always been there; it's like water"'.)

19 As Lessig wrote, " $[\mathrm{b}] \mathrm{y}$ working through ... examples of law interacting with cyberspace, we will throw into relief a set of general questions about law's regulation outside of cyberspace" The law of the horse: what cyberlaw might teach, «Harvard Law Review», 113 (1999), p. 502. Juliano Maranhão's recent work offers similar insight, cf. JULIANO MARANHÃO, Reconfiguração conceitual? O direito digital como metáfora de si mesmo, in P. R. B. FORTES, R. J. F. DE CAMPOS, S. BARBosA (eds.), Teorias contemporâneas do direito: o direito e as incertezas normativas, Juruá, Curitiba, 2016, pp. 97-128. 


\section{Revisiting anonymity}

I will advance the argument that shifts brought by the internet compel us to abandon the reading of the anonymity clause as an identification requirement. My point is not that the technological advances of the internet create a need for 'updating' existing law or 'translating' it to a new digital era, but rather that the established interpretation of the clause fails to account for how our social and legal practices, when properly understood, already recognise how anonymity is employed in the service of vital constitutional values. By confronting us with an implication of our understanding of anonymity we are forced to see as absurd, the emergence of the internet prompts a re-examination of our conceptions. I will propose an alternative interpretation of the constitutional clause which offers a comprehensive account of how freedom of expression and the right to privacy require respect for anonymity on the internet.

My point is not to produce a general theory of anonymity ${ }^{20}$, nor of digital anonymity even. Again, my goal is advancing an alternative interpretation of the anonymity clause of the Brazilian constitution that does not take it to be synonymous with requiring identification whenever 'thoughts' are 'expressed,21.

Determining whether the identification-requirement reading of the constitution holds is not a question that will be helped by providing a definition of anonymity or by conceiving of an abstract theory of

\footnotetext{
${ }^{20}$ For that endeavour, see JEFFREY M. SKOPEK, Anonymity, the production of goods, and institutional design, «Fordham Law Review», 82/4 (2014), pp. 1751-809.

21 While art. 5, IV, of the Brazilian constitution, is generally cited as asserting the right to freedom of expression, I should highlight the language of that provision is quite encompassing. It reads: 'é livre a manifestação de pensamento, sendo vedado o anonimato'. I have above cited Keith Rosenn's translation of the provision as 'manifestation of thought is free, but anonymity is forbidden', Constitution of the Federative Republic of Brazil: October 5, 1988 (as Amended to September 15, 2015), cit. I would stress that manifestation might be replaced by externalising or expressing. I will adopt the latter as it seems more naturally intelligible on its own. At any rate, the key point here is that a constitutional right protecting 'the expression of thought is remarkably broad, precluding language-based objections on whether it expressly applies beyond written speech, for instance.
} 
anonymity. It is plainly an interpretive question about the practices of a community which assumes they are in the service of a point or value and, crucially, which recognises those practices to be 'sensitive to its point, so that... rules must be understood or applied or extended or modified or qualified or limited by that point ${ }^{, 22}$. The only manner of settling the question of whether that reading of the anonymity clause is sound is therefore to argue about whether its account of the constitution rests on the best case for understanding our legal practices and values. We thus sort out the dispute by engaging in interpretation, as we 'strive... to make an object the best it can be, as an instance of some assumed enterprise ${ }^{23}$.

That is, of course, a statement of Ronald Dworkin's legal interpretivism ${ }^{24}$. Under this theory, arguing about interpretation is how we resolve controversies about the law. We assess an interpretation on two distinct, yet intertwined, dimensions ${ }^{25}$ : we examine how it fits existing practices

\footnotetext{
${ }^{22}$ RonAld DwORKIn, Law's empire, Harvard, Cambridge (Mass.) \& London, 1986, p. 47.

${ }^{23}$ RONALD DwORKIN, Law's empire, cit., p. 53.
}

24 Dworkin is mostly known in Brazil for his 1967 article advancing the notion of legal principles as structurally different from legal rules. RONALD DWORKIN, The model of rules, «The University of Chicago Law Review», 35 (1967), pp. 14-46. See VIRGílio AfONSO DA SiLva, Princípios e regras: mitos e equívocos acerca de uma distinção, «Revista Latino-Americana de Estudos Constitucionais», 1 (2003), p. 610; Luís R. BARROSO, Here, there, and everywhere: human dignity in contemporary law and in the transnational discourse, «Boston College International \& Comparative Law Review», 35 (2012), p. 355; MARIANA C. E. Melo, The "Marco Civil da Internet" and its unresolved issues: free speech and due process of law, cit., p. 31. Yet Dworkin would, in the following years, veer from that early attack on legal positivism to this focus on interpretation, which is dominant in his later work. Ronaldo Porto Macedo Jr suggests Dworkin actually rejected this distinction as early as 1977, with Taking rights seriously. RONALDO P. MACEDO JR, Do xadrez à cortesia: Dworkin e a teoria do direito contemporânea, Saraiva, São Paulo, 2013, pp. 44-45.

25 '[...] the two dimensions of fit and value represent different aspects of a single overall judgement of political morality'. RONALD DWORKIN, Justice in robes, Harvard, Cambridge (Mass.), 2006, p. 15. While bisecting the components of the argument is of use for the structure of the text, I should note the dimensions of fit and justification are not wholly separate, but interdependent. See: 'It is important not only to notice this contrast between elements of artistic freedom and textual constraint but also not to misunderstand its character. ... For the constraints that you sense as limits to your freedom to read A Christmas Carol so as to make Scrooge irredeemably evil are as much matters of judgment and conviction, about which different chain novelists might disagree[...]' RONALD DWORKIN, Law's empire, cit., p. 234. See also DIMITRIOS KYRITSIS, Shared authority: courts and legislatures in legal theory, Hart, Oxford, 2015, pp. 5763. Lawrence Solum has argued this connected notion of the two dimensions of interpretation is a development in the work of Dworkin: 'Whereas the theory of interpretation offered in Hard Cases seemed to be a two-step theory, the theory offered in Law's Empire looked like a one-step theory. Fit and justification were not two distinct moments in the interpretive enterprise; rather, 
and whether its account offers compelling justification of the value instantiated by those practices ${ }^{26}$.

Dworkin famously presented his account of an interpretive practice through the fanciful example of 'an invented community' governed by the 'rules of courtesy' ${ }^{\text {,2 }}$. At first, courtesy is taken to serve the 'show [ing] of respect to social superiors', and thus to command that peasants take their hats off to nobility. 'For a time', Dworkin explains, 'this practice has the character of taboo: the rules are just there and are neither questioned nor varied ${ }^{28}$; this changes as the members of the community develop an interpretive attitude towards courtesy. Then, the very point of courtesy is disputed, and 'people begin to demand, under the title of courtesy, forms of deference previously unknown or to spurn or refuse forms previously honored, with no sense of rebellion, claiming that true respect is better served by what they do than by what others did, ${ }^{29}$.

As the community is persuaded by the arguments supporting those novel demands, the practice develops. The point of courtesy might be thought of as showing respect for age, rather than social class, and thus what the community had previously understood as a clear requirement of courtesy - for instance, that an old carpenter take his hat off to a boyish prince might then be taken to instantiate the opposite, lack of courtesy. So what was once a paradigm of courtesy, 'that is, as requirements of courtesy if anything is ${ }^{30}$, might be rejected when faced with transformations affecting the community. While generally endorsed, those paradigms are a touchstone for interpretation: 'argument against an interpretation will take the form, whenever this is possible, of showing that it fails to include or account for a paradigm case ${ }^{31}$. Yet paradigms are not invulnerable:

justification now does all the normative work and fit merely identifies that which must be justified'. The unity of interpretation, «Boston University Law Review», 90 (2010), p. 555.

${ }^{26}$ RONALD DWORKIN, Justice in robes, cit., p. 15.

${ }^{27}$ RONALD DWORKIN, Law's empire, cit., p. 47.

${ }^{28}$ RONALD DWORKIN, Law's empire, cit., p. 47.

${ }^{29}$ RONALD DWORKIN, Law's empire, cit., p. 48.

${ }^{30}$ RONALD DWORKIN, Law's empire, cit., p. 72.

${ }^{31}$ RONALD DwORKIN, Law's empire, cit., p. 72. 
given that the community endorses the interpretive attitude, a paradigm must yield if challenged by a new interpretation of the practice that is superior in fit and justification.

It is fair to admit the identification requirement reading of the Brazilian constitution is a paradigm of constitutional interpretation of anonymity and freedom of expression. It is a pervasive, long-held view of what the constitution requires. This dissertation will challenge that paradigm. I will argue it is ill-considered in its general negative outlook of anonymity and insufficient in its appraisal of freedom of expression and the right to privacy.

Again, I do not contend that the paradigm is made invalid by the internet, or does not hold for the internet only. An illustration provided by Dworkin is useful to make this point. Suppose the community of courtesy accepts for some time that the point of the practice is to show respect for women, so requiring, as paradigmatic of the practice, that men rise when a woman enters the room. Broader transformations affecting the community, Dworkin explains, might engender that paradigm to be discarded as 'an unrecognized anachronism', and so '[y]esterday's paradigm would become today's chauvinism ${ }^{\text {, } 2}$. Yet that new realisation does not entail the practice was ever justified.

\section{A roadmap of the argument}

To understand disseminated claims about the anonymity clause, the argument begins at chapter 1 with an examination of the Press Act of 1967, which seems to be the model basing the prevailing interpretation of the constitution. This act established a scheme for effecting the identification paradigm. We will inspect that scheme and consider its

\footnotetext{
${ }^{32}$ RONALD DwORKIN, Law's empire, cit., pp. 72-73.
} 
limitations as a project for implementing the identification requirement more generally.

Chapter 2 then inspects established practices in Brazilian law that are inconsistent with the claim of an unrestricted identification requirement and the view that securing liability is paramount in the Brazilian constitution. A number of instances - the secret ballot, secrecy of jury deliberations, reporter's privilege and anonymous crime reporting - attest that it is not the case. Those cases show that the question must turn on the substantive issue.

We take up that issue starting in chapter 3 , which considers three different theories of the justification of freedom of expression, the argument from truth, the argument from self-government and the argument from dignity. It establishes that only if we understand freedom of expression as (at least primarily) an aspect of dignity we are able to understand commitments from that constitutional right that fail to obtain under the other theories. This is clearly the case with the constitutional ban on censorship, and it is also the best understanding of the Brazilian Supreme Court holding for unauthorised biographies.

As we review, in chapter 4, the case for anonymity to be found in the precedents of the US Supreme Court, those three theories will serve us well. We will explore how the internet enables a transformation in social interaction by allowing anonymous personal expression. We probe arguments and objections considering all this, and focus particularly on how dignity offers an important insight to the court's insistence that 'an author's decision to remain anonymous, like other decisions concerning omissions or additions to the content of a publication, is an aspect of the freedom of speech ${ }^{33}$. As we also see in chapter 4, the ramifications from this insight for anonymous internet access suggest an overlap between freedom of expression and the right to privacy.

$33 \quad$ McIntyre v Ohio Elections Comission 514 US 334, 342 (1995). 
As the right to privacy is generally understood as instrumentally valued and dignity insists conversely on an inherent-value account of freedom of expression, this might be taken to imply a conflict. Instead, as we will explore in chapter 5, appreciating the right to privacy as an aspect of dignity is essential to a reliable account of important questions in digital surveillance and constraints on government power. The right to privacy as an aspect of dignity will also illustrate how mandating identification negating anonymity - fails to show concern for the private life of individuals.

These discussions are recollected and summarised in chapter 6, which examines the legal framework of the internet in Brazil and how the identification paradigm relates to it. It also proposes new understanding of the issues involved in anonymous internet access, anonymous platforms, and anonymous posts. A final section of the chapter puts forward procedural safeguards for online anonymous expression. 


\section{CONCLUSION}

The internet presents a special challenge for the established understanding of anonymity in Brazilian constitutional law. Anonymity has long been held in disrepute by the prevailing literature. ${ }^{358}$ The traditional understanding of freedom of expression assigns it no value; it insists on a reading of the constitution under which freedom of expression may only be claimed by those in compliance with the identification requirement it establishes.

Identification is paramount, it is asserted, as the constitution insists on a model of 'freedom and responsibility",359, so there must always be someone who will be held liable for abusive speech. The identification requirement is the price to be paid by exercising freedom of expression, and it is a reasonable price to pay, many argue ${ }^{360}$. José Afonso da Silva provides a perfect illustration of this understanding:

Freedom of expression has its burdens, such as that one exercising it must assume responsibility for the resulting

\footnotetext{
${ }^{358}$ ÊNiO S. ZULIANI, Art. $7^{\circ}$, cit., p. 159; DARCY A. MirANDA, Art. $7^{\circ}$, cit., p. 110; AlEXANDRE DE MORAES, Liberdade de pensamento, cit., p. 130.

${ }^{359}$ DANIEL SARMENTO, Comentários ao art. $5^{\circ}, \mathrm{IV}$, cit.

360 'Free expression of thought is compensated by the prohibition of anonymity' ('A livre expressão do pensamento tem por contrapartida a proibição do anonimato'), MANOEL G. FERREIRA FILHO, Art. $5^{\circ}$, IV , cit., p. 31; similarly Juliana ABRUSIO, Os limites da liberdade de expressão na internet, cit., p. 120; JosÉ CRETElla NeTO, Art. $7^{\circ}$, cit., pp. 76-78; ÊNIO S. ZULIANI, Art. $7^{\circ}$, cit., pp. 158-159; DARCY A. MirandA, Art. $7^{\circ}$, cit., p. 110; UADI L. BUlOS, Art. $5^{\circ}, I V$, cit., p. 122.
} 
expressed ideas, in order that, should it be the case, one may be held liable for the damage caused onto others. ${ }^{361}$

Chapter 1 examined the Press Act of 1967, considering how the identification requirement could be implemented in practice - an important point which the literature has so far ignored. We explored how the strategies employed by that act - mandated registration, the associated notion of 'illegal newspapers' subject to apprehension by the police, and secondary liability determined by legally-defined attribution of otherwise anonymous writings - draw heavily on the structure of traditional media. The oligopolistic character of that industry is crucial for enforcement of its implementation of the identification paradigm.

We further considered how a substantive question is also contextdependent: as traditional media are particularly defined by editorial judgement, it might make sense to hold a newspaper, for instance, liable for an anonymous text it elected to disseminate. Yet, transposing those strategies to a general imposition on anyone engaging in 'expression of thought' is an entirely different question - one commentators of the Press Act of 1967 mostly rejected as unworkable and, we should again highlight, substantively distinct. Even the authoritarian Press, Act, we noted, did not meet the more encompassing demands of the identification paradigm. Nor could it, because it would simply be unfeasible to monitor every utterance of expressive act for identification. Applying the identification requirement to the internet would make this kind of surveillance possible, profiting from its architecture. Yet, is this the proper understanding of the Brazilian constitution, that it mandates surveillance of all expression?

We then turned to the question of whether the identification-requirement paradigm is truly an adequate account of practices the Brazilian constitution is conventionally thought to protect. Chapter 2 thus

\footnotetext{
361 JosÉ AfONSO DA SILVA, Art. $5^{\circ}$, IV, cit., p. 92. 'A liberdade de manifestação do pensamento tem seus ônus, tal como o de o manifestante identificar-se, assumir claramente a autoria do produto do pensamento manifestado, para, sendo o caso, responder por eventuais danos a terceiros'.
} 
considered instances where the constitution clearly does not hold identification and liability to be paramount. The secret ballot, an essential feature of Brazilian democracy, is a patent example of this ${ }^{362}$, and so is the secrecy of jury deliberations. While liability in these cases could be an issue (voters and jurors may engaging in vote selling, for instance), it is limited by context, of course. This still does not alter the fact that identification itself is not pursued in these instances. The opposite, actually: the law seeks anonymity.

The protection of anonymous sources is also an example of the constitution safeguarding anonymity at the expense of the identification requirement. It may of course be said that journalists and media are responsible intermediates and act as gatekeepers in this context ${ }^{363}$, but again the identification requirement is not met, and liability itself is in jeopardy. While the privilege does not secure journalists from being ordered to pay damages for negligence in verification and lack of professional diligence as regards the information itself, the protection of anonymous sources effectively operates as a shield for liability from the manner the information was acquired. It protects cover for illicit conduct of the anonymous source who, for instance, violates a confidentiality duty.

These are all instances provided by the constitution explicitly, so an objection could be raised that exceptions to the general rule of identification must be explicitly provided for in the constitution. Yet the case law on anonymous reporting of criminal activity, and the adoption of Crimestopper schemes by government agencies attest otherwise. This is a case where the identification requirement would have the strongest claim, since answering to criminal investigation or prosecution is a very

362 SAUl LEVMORE, The anonymity tool, cit., p. 2219 ff.; JeFFrey M. SKOPEK, Anonymity, the production of goods, and institutional design, cit., p. 1763. Contra, Eric Barendt argues that the secret ballot is not an instance of anonymity; yet it is still a clear case that identification is not always preferred. ERIC BARENDT, Anonymous speech, the secret ballot and campaign contributions, cit.

${ }^{363}$ ERIC BARENDT, The protection of anonymous sources, cit. 
serious repercussion resulting from anonymous speech, which the prevailing understanding of the constitution regards as of no value.

These cases show that a general identification requirement cannot be affirmed. The constitution contains provisions explicit inconsistent with it, and other admitted practices are also incompatible with it. A proper appreciation of what is at stake cannot be reached before we consider what values anonymity may serve.

In chapter 3, we began considering that question, starting with freedom of expression. We discussed theories providing justification for freedom of expression. We inspected the widely disseminated argument from truth, most famously put forward by John Stuart Mill, and the marketplace of ideas variant. We found that we have strong reasons to be sceptical of it, mainly for it seems unclear truth is always best served by freedom of expression. At best, the argument from truth and the marketplace theory are decisively underinclusive of what we take freedom of expression to protect.

We then considered the theory which associates freedom of expression with self-government, which we referred as the Madisonian ideal. While certainly valuable, self-government does not provide a theoretical basis for our understanding of freedom of expression. It condemns clandestine government censorship, as Dworkin put it, yet cannot explain why the majority would be wrong to democratically opt for censorship. Lastly, we turned to Ronald Dworkin's theory which connects freedom of expression to a partnership conception of democracy and to dignity.

If government is to have a moral title to coerce, this theory holds, it must respect freedom of expression. This constitutive justification of freedom of expression attaches political legitimacy to equality and dignity. We found it provides a better account of our understanding of freedom of expression, and we examined how censorship is a clear example of it. The Millsian argument from truth or the Madisonian ideal would offer no reason why the majority cannot empower government to transparently censor individuals; they would consent to democratic censorship. A constitutive justification of freedom of expression would not, however: it 
would reject 'democratic censorship' as an oxymoron. This provides a powerful basis for the provisions against censorship in the Brazilian constitution, and it also seems essential to understanding the holding of the Brazilian Supreme Court in the unauthorised biographies case (ADI $4815)$.

Chapter 4 then turned to anonymity itself. It surveyed US first amendment doctrine on anonymity, as reflected by the Supreme Court cases Talley, McIntyre, and Watchtower Bible. We conceded to the criticism of Eric Barendt that instrumental justifications did seem insufficient. The same cannot be said, however, of a constitutive justification approach. We understood the force of the argument of the McIntyre court that disclosure of identification was as a decision for the author just as much as additions or omissions in the content of the speech were. We surveyed online platforms for anonymous communication and found that Barendt is wrong in contending that anonymity prevents meaningful communication. Internet anonymity enables new forms of communication and social engagement. In light of this, we concluded that identification is expressive, and freedom of expression must protect this decision of speakers - this is the strong argument the McIntyre court offers us.

As we considered, in the final sections of chapter 4, what those freedom of expression principles mean to internet access and internet posting, we noted that the protection it offers is entangled with what we take the right to privacy to safeguard. That entanglement suggested an important tension, since privacy is widely considered to be instrumentally valuable.

Chapter 5 then addressed that tension, drawing on our conclusions about anonymity, proposed a tentative account of privacy as an inherently valuable aspect of dignity. Discussing the proscription of general warrants under this new light, we explored how such an interpretation of the value of privacy is better equipped to deal with emerging conflicts. A constitutive justification of the right to privacy, focusing on power, dignity, and equality, in similar fashion to our constitutive justification of freedom of expression, has important implications for the protection of anonymity, we noted. It also illuminates how privacy is a critical aspect 
of the ethical independence and respect democratic communities must appreciate in all its members.

Finally, in chapter 6, we considered the implications of these discussions in reinterpreting Brazilian law concerning anonymity. We noted Marco civil da internet does not abide by the identification requirement reading of the constitution, and rightly so. Instead, it clearly allows for the use of online anonymity tools such as Tor, a free and open source solution, thus explicitly exempted from the date retention mandate. We also examined how the immunity that statute confers on application providers makes it possible for anonymous platforms to operate, as long as they comply with court orders for removal of infringing content. We then turned to anonymous content itself and reflected on a suggestion for ensuring users are shown the due process the Brazilian constitution affords them.

We have considered a number of theoretical and practical questions relating to anonymity. Those discussions offered fatal grounds for rejecting the identification paradigm. We did not, however, arrive at a formulation of the anonymity clause which provides a clear test for when it would be wrong to compel identification. I am afraid no litmus test is available here, as none is available with freedom of expression or the right to privacy more generally. This should not be thought of as a shortcoming of the argument: as we acknowledge those are interpretative questions of our values and practices, a promptly-administrable rule or a definitional phrase would be less productive than many would expect. Instead, this points to an important conclusion of our discussion: supporters of the identification paradigm seem to espouse the notion that the anonymity clause may be interpreted without reference to basic values endorsed by the Brazilian constitution. The argument we have entertained insists we must never lose sight of those values in adjudicating identification and anonymity. 


\section{REFERENCES}

ABrusio, Juliana, Os limites da liberdade de expressão na internet, in Educação digital, 2016, pp. 107-21.

AfOnso DA Silva, José, Art. $5^{\circ}, I V$, in Comentário contextual à

Constituição, Malheiros, São Paulo, 2012, pp. 91-3.

Afonso da Silva, Virgílio, Direitos fundamentais: conteúdo essencial, restrições e eficácia, Malheiros, São Paulo, $2014^{2}$.

Antonialli, Dennys M., Cruz, Francisco de B. \& VAlente, MARIANA G., Existe um “direito de saber quem é quem” na Internet? $(2014)<\mathrm{http}$ //link.estadao.com.br/blogs/deu-nosautos/existe-um-direito-de-saber-quem-e-na-internet/>, accessed 11.Sep.2017.

AUSTIN, LiSA M., Enough about me: why privacy is about power, not consent (or harm), in A World without Privacy (What Law Can and Should Do?), Cambridge, New York, 2014, pp. 131-89.

BADARÓ, GuSTAVO, A boca do leão: validade das interceptações telefônicas decretadas com base em notitia criminis anônima, «Revista dos Tribunais» 927 (2013), pp. 529-53.

BAKER, C E., Human liberty and freedom of speech, Oxford, New York, 1989.

BAKER, C E., Autonomy and free speech, «Constitutional Commentary» (2011), pp. 251-82.

BARENDT, ERIC, Why protect free speech?, in Freedom of speech, Oxford, Oxford, 2005, pp. 1-38.

BARENDT, ERIC, Prior restraints, in Freedom of speech, 2005, pp. 117 53. 
BARENDT, ERIC, Anonymous speech in English law, in Anonymous speech: literature, law and politics, Hart Publishing, 2016, pp. 8197.

BARENDT, ERIC, Anonymous speech, the secret ballot and campaign contributions, in Anonymous speech: literature, law and politics, Hart Publishing, 2016, pp. 156-69.

BARENDT, ERIC, The protection of anonymous sources, in Anonymous speech: literature, law and politics, Hart Publishing, 2016, pp. 98121.

BARENDT, ERIC, Anonymity and freedom of speech, in Anonymous speech: literature, law and politics, Hart Publishing, 2016, pp. 5680.

BARENDT, ERIC, Anonymity on the Internet, in Anonymous speech: literature, law and politics, Hart Publishing, 2016, pp. 122-54.

Behne, Klaus-ERnst \& Wöllner, Clemens, Seeing or hearing the pianists? A synopsis of an early audiovisual perception experiment and a replication, «Musicae Scientiae» 15(3) (2011), pp. 324-42.

Bloom, Lackland H., New York Times v. Sullivan, in Do great cases make bad law, 2014, pp. 253-66.

BODLE, ROBERT, The ethics of online anonymity or Zuckerberg vs. "Moot," «ACM SIGCAS Computers and Society» 43(1) (2013), pp. 22-35.

BOEHME-NEßLER, VolKer, Privacy: a matter of democracy. Why democracy needs privacy and data protection, «International Data Privacy Law» 6(3) (2016), pp. 222-9.

Boudin, Chesa, Publius and the petition: Doe v. Reed and the history of anonymus speech, «The Yale Law Journal» 120 (2011), pp. 2140-81.

Bulos, Uadi L., Art. $5^{\circ}$, IV in Comentários à Constituição Federal de 1988, São Paulo, $2014^{11}$, pp. 121-6.

Cabello, Marcos A. A., Da guarda de registro de acessos a aplicações de internet, in G. S. LEITE, R. LEMOS (eds.), Marco civil 
da internet, Atlas, São Paulo, 2014.

CAPANEMA, WALTER A., $O$ direito ao anonimato: uma nova interpretação do art. $5^{\circ}, I V, C F$, in Jurisdição constitucional, democracia e direitos fundamentais, 2012, pp. 543-58.

Chamber of Deputies (BraziL), Civil framework of the Internet, ALICE, F. B. (trad.), Chamber of Deputies (Brazil), Brasília, 2016.

COHEN, JUlie E., A right to read anonymously: a closer look at "copyright management" in cyberspace, "Connecticut Law Review» 28 (1996), pp. 981-1039.

Cretella Neto, José, Art. $7^{\circ}$, in Comentários à lei de imprensa, Forense, Rio de Janeiro, 2008, pp. 76-81.

CUNHA, FERNANDO W. D., Evolução do direito eleitoral brasileiro, «Revista de Informação Legislativa» 16(63) (1979), pp. 113-8 $<$ http://www2.senado.leg.br/bdsf/handle/id/181137>.

De Choudhury, Munmun \& De, Sushovan, Mental health discourse on reddit: self-disclosure, social support, and anonymity (2014).

Donohue, Laura K., The original Fourth Amendment, «The University of Chicago Law Review» 83(3) (2016), pp. 1181-328.

DWORKIn, RONALD, The model of rules, «The University of Chicago Law Review» 35 (1967), pp. 14-46.

DWORKIN, RONALD, Taking rights seriously, Harvard, Cambridge, 1977.

DWORKIN, RONALD, What rights do we have?, in Taking rights seriously, Harvard, Cambridge, 1977, pp. 266-78.

DWORKIN, RONALD, Liberty and liberalism, in Taking rights seriously, Harvard, Cambridge, 1977, pp. 259-65.

DWORKIN, RONALD, Is there a right to pornography?, «Oxford Journal of Legal Studies» 1(2) (1981), pp. 177-212.

DWORKIN, RONALD, A matter of principle, Oxford, Oxford, 1985.

DWORKIN, RonALD, Law's empire, Harvard, Cambridge (Mass.) \& 
London, 1986.

DWORKIN, RONALD, Why must speech be free?, in Freedom's law, Oxford, Oxford, 1999, pp. 193-213.

DwOrkin, RonalD, Pornography and hate, in Freedom's law, Oxford, Oxford, 1999, pp. 214-26.

DWORKIN, RoNALD, Freedom's law, Oxford, Oxford, 1999.

Dworkin, Ronald, Justice in robes, Harvard, Cambridge (Mass.), 2006.

DWORKIn, Ronald, A new map of censorship, «Index on Censorship» 35(1) (2006), pp. 130-3.

DWORKIN, RonalD, Is democracy possible here?, Princeton, Princeton, 2008.

DWORKIn, RONALD, Justice for hedgehogs, Harvard, Cambridge (Mass.) \& London, 2011.

EASTERBROOK, FranK H., Cyberspace and the law of the horse, «The University of Chicago Legal Forum» (1996), pp. 207-16.

EATON, KIT, Surprising, scandalous, serious, even inspiring, published in New York TImes, 2014, p. B10 $<$ https://www.nytimes.com/2014/08/14/technology/personaltech/su rprising-scandalous-serious-even-inspiring.html $>$.

EMERSON, THOMAS I., The doctrine of prior restraint, «Law and Contemporary Problems» 20(4) (1955), pp. 648-71.

Ferreira Filho, Manoel G., Art. $5^{\circ}, \mathrm{IV}$, in Comentários à Constituição brasileira de 1988, Saraiva, São Paulo, 2000, pp. 301 .

FINLEY, KLINT, VPNs won't save you from congress' internet privacy giveaway $(2017)<\mathrm{https} / /$ www.wired.com/2017/03/vpns-wontsave-congress-internet-privacy-giveaway/>, accessed 28.Apr.2017.

FRARY, MARK, Leave no trace: Five ways to increase your privacy when browsing online, «Index on Censorship» 45(3) (2016), pp. 51-3. 
FroOMKIN, A M., Legal issues in anonymity and pseudonymity, «The Information Society» 15(2) (1999), pp. 113-27.

Froomkin, A M., From anonymity to identification, «Journal of SelfRegulation and Regulation» 1 (2015), pp. 120-39.

GiACOBBO, Elisa O., A "notitia” anônima de crime e a vedação do anonimato, «Revista Jurídica» 57(386) (2009), pp. 95-147.

GLEICHER, NATHANIEL, John Doe subpoenas: toward a consistent legal standard, «The Yale Law Journal» 118 (2008), pp. 320-68.

GODINHO, ADRIANO M. \& ROBERTO, WiLsOn F., A guarda de registros de conexão: o Marco Civil da Internet entre a segurança na rede e os riscos à privacidade, in G. S. LEITE, R. LEMOS (eds.), Marco civil da internet, Atlas, São Paulo, 2014.

Gross, Clarissa P., Pode dizer ou não? Discurso de ódio, liberdade de expressão e a democracia liberal igualitária, Faculdade de Direito da Universidade de São Paulo, 2017.

GUEST, STEPHEN, Ronald Dworkin, Stanford, Stanford, $2012^{3}$.

HaWorth, Alan, On Mill, infallibility, and freedom of expression, «Res Publica» 13(1) (2007), pp. 77-100.

HoAng, NguYen P. \& PishVa, Davar, Anonymous communication and its importance in social networking (2016), pp. 34-9.

Hungria, Nelson, A disciplina jurídica da liberdade de pensamento e informação, «Revista dos Tribunais» 57(397) (1968), pp. 9-18.

ISAAC, MIKE, Facebook developing app that allows anonymity (2014) $<$ https://bits.blogs.nytimes.com/2014/10/07/facebook-readies-appallowing-anonymity>, accessed 31.Aug.2017.

JARDINE, ERIC, The dark web dilemma: Tor, anonymity and online policing (2015).

KALIA, AMUL, Here's how to protect your privacy from your internet service provider (2017)

$<$ https://www.eff.org/deeplinks/2017/04/heres-how-protect-yourprivacy-your-internet-service-provider>, accessed 31.Jul.2017. 
KAMINSKI, MARGOT E., Real masks and real name policies: applying anti-mask case law to anonymous online speech, «Fordham Intellectual Property, Media and Entertainment Law Journal» 23(3) (2013), pp. 815-96.

KAng, RuOgu, DabBish, Laura A. \& SutTon, Katherine, Strangers on your phone: Why people use anonymous communication applications (2016), pp. 358-69.

KAPlan, Jonas T., Gimbel, SARAH I. \& HARRIS, SAM, Neural correlates of maintaining one's political beliefs in the face of counterevidence, «Scientific Reports» 6(1) (2016), p. 217.

Kaplan, Jonas T., Gimbel, Sarah I., Dehghani, Morteza, IMMORDINO-YANG, MARY H., ET AL., Processing narratives concerning protected values: a cross-cultural investigation of neural correlates, «Cerebral Cortex» (2016), p. bhv325.

KUROSAWA, KAORI \& DAVIDSON, JANE W., Nonverbal behaviours in popular music performance: A case study of The Corrs, «Musicae Scientiae» 9(1) (2016), pp. 111-36.

LEAVITT, ALEX, "This is a throwaway account": temporary technical identities and perceptions of anonymity in a massive online community (2015), pp. 317-27.

LEONARDI, MARCEL, Responsabilidade civil dos provedores de serviços de internet, Juarez de Oliveira, São Paulo, 2005.

LEONARDI, MARCEL, A garantia fundamental do direito à privacidade e à liberdade expressão nas comunicações como condição ao pleno exercício do direito de acesso à internet, in G. S. LEITE, R. LEMOS (eds.), Marco civil da internet, Atlas, São Paulo, 2014, pp. 622-33.

LESSIG, LAWRENCE, Reading the Constitution in cyberspace, «Emory Law Journal» 45 (1996), pp. 869-910.

LESSIG, LAWRENCE, The law of the horse: what cyberlaw might teach, «Harvard Law Review» 113 (1999), pp. 501-46.

Lessig, Lawrence, Code, Basic Books, New York, $2006^{2}$.

LEVER, ANNABELle, Privacy, democracy and freedom of expression, in 
B. Roessler, D. Mokrosinska (eds.), Social Dimensions of Privacy (Interdisciplinary Perspectives), Cambridge University Press, Cambridge, 2015, pp. 162-80.

LEVMORE, SAUL, The anonymity tool, «University of Pennsylvania Law Review» 144 (1996), pp. 2191-236.

LIDSKY, LYRISSA B., Anonymity in cyberspace: what can we learn from John Doe?, «Boston College Law Review» 50 (2009), pp. 137391.

LIDSKY, LYRISSA B. \& COTTER, THOMAS F., Authorship, audiences, and anonymous speech, «Notre Dame Law Review» 82(4) (2007), pp. 1537-604 <http://scholarship.law.nd.edu/ndlr/vol82/iss4/4/>.

LIMA, CínTIA R. P. DE, A responsabilidade civil dos provedores de aplicação de internet por conteúdo gerado por terceiro antes e depois do Marco Civil da Internet (Lei n. 12.965/14), «Revista da Faculdade de Direito da Universidade de São Paulo» 110 (2015), pp. 155-76.

LOSHIN, PETER, Practical anonymity: Hiding in plain sight online, Syngress, Waltham (MA), 2013.

LuCAs, GeOrge R., JR, Privacy, anonymity, and cyber security, «Amsterdan Law Forum» 5(2) (2013), pp. 107-14.

MACEDO, RONALDO P., JR, Freedom of expression: what lessons should we learn from US experience?, «Revista Direito GV»13(1) (2017), pp. 274-302

$<$ http://bibliotecadigital.fgv.br/ojs/index.php/revdireitogv/article/vi ew/68919>.

MARMOR, ANDREI, What is the right to privacy?, «Philosophy \& Public Affairs» (2015).

MARTINS, LEONARDO, Lei de imprensa entre limite e configuração da ordem constitucional da comunicação social, in Liberdade e estado constitucional, Atlas, São Paulo, 2012, pp. 239-77.

MARTINVIITA, ANNAMARI, Online community and the personal diary: Writing to connect at Open Diary, «Computers in Human 
Behavior» 63 (2016), pp. 672-82.

MCNeAly, JaSmine, Textual analysis of the influence of McIntyre $v$. Ohio Elections Commission in cases involving anonymous online commenters, «First Amendment Law Review» 11(1) (2013), pp. 149-71

$<$ http://heinonline.org/HOL/Page?handle=hein.journals/falr11\&g_s ent $=1 \&$ collection $=$ journals\&id $=157>$.

Medeiros, Francis A. \& Bygrave, Lee A., Brazil's 'Marco Civil da Internet': Does it live up to the hype?, «Computer Law \& Security Review» 31(1) (2015), pp. 120-30.

Melo, Mariana C. E., The "Marco Civil da Internet" and its unresolved issues: free speech and due process of law, CRV, Curitiba, 2016.

Melo, Mariana C. E., Anonimato, proteção de dados e devido processo legal: por que e como conter uma das maiores ameaças ao direito à privacidade no Brasil (2017).

MiLl, John S., GRAY, J. (ed.), “On liberty” and other essays, Oxford, Oxford, 1998.

MINÁRIK, TOMÁŠ \& OSUlA, ANNA-MARIA, Tor does not stink: Use and abuse of the Tor anonymity network from the perspective of law, «Computer Law \& Security Review» 32(1) (2016), pp. 111-27.

Miranda, DarCy A., Art. $7^{\circ}$, in Comentários à lei de imprensa, RT, São Paulo, 1994.

Monteiro, RenAto L., Da proteção aos registros, aos dados pessoais e às comunicações privadas, in F. Del MASSO, J. ABRUSIO, M. A. FLORÊNCIO FILHO (eds.), Marco civil da internet: lei 12.965/2014, RT, São Paulo, 2014, pp. 139-53.

MOORE, SUSANNA, The challenge of internet anonymity: protecting John Doe on the internet, «John Marshall Journal of Computer and Information Law» 26(4) (2009), pp. 469-85 $<$ http://repository.jmls.edu/jitpl/vol26/iss4/2>.

Moraes, AleXANDRE DE, Liberdade de pensamento, in Constituição do 
Brasil interpretada e legislacão constitucional, Atlas, São Paulo, 2011, pp. 129-32.

Moraes, AleXANDRE DE, Constituição do Brasil interpretada e legislacão constitucional, Atlas, São Paulo, 2011.

NisSENBAUM, Helen, The meaning of anonymity in an information age, «The Information Society» 15(2) (1999), pp. 141-4.

NitRINI, RODRIGO V., Liberdade de informação e proteção ao sigilo de fonte: desafios constitucionais na era da informação digital, Faculdade de Direito da Universidade de São Paulo, São Paulo, 2013.

Noman, Helmi, Arab religious skeptics online: anonymity, autonomy, and discourse in a hostile environment (2015), pp. 1-30.

NuCCI, GuILHERME DE S., Tribunal do júri, Forense, Rio de Janeiro, $2015^{6}$.

NYHAN, BRENDAN \& REIFLER, JASON, When corrections fail: the persistence of political misperceptions, «Political Behavior» 32(2) (2010), pp. 303-30.

Pontes De MiRANDA, Francisco C., Liberdade de pensamento, in Comentários à Constituição de 1946, vol. 4, Rio de Janeiro, 1960², pp. 419-36.

Pontes de Miranda, Francisco C., Comentários à Constituição de 1967, com a Emenda n. 1, de 1969, vol. 5, Revista dos Tribunais, São Paulo, $1971^{2}$.

Pontes de Miranda, Francisco C., Comentários ao código de processo civil, Forense, Rio de Janeiro, $2005^{2}$.

Post, DAVID G., Pooling intellectual capital: thoughts on anonymity, pseudonymity, and limited liability in cyberspace, "The University of Chicago Legal Forum» (1996), pp. 139-69.

POST, ROBERT C., The constitutional concept of public discourse: outrageous opinion, democratic deliberation, and Hustler Magazine v. Falwell, «Harvard Law Review» 103(3) (1990), pp. 601-86<http://digitalcommons.law.yale.edu/fss_papers/210>. 
REIDENBERG, JOEL R., The transparent citizen, «Loyola University Chicago Law Journal» 47 (2015), pp. 437-63.

RICHARDS, NeIL M., Intellectual privacy, «Texas Law Review» 87 (2008), pp. 387-445.

RICHARDS, NEIL M., The dangers of surveillance, «Harvard Law Review» 126(7) (2013), pp. 1934-65.

Rosa, LeONARdo G. P., O liberalismo igualitário de Ronald

Dworkin: o caso da liberdade de expressão, Universidade de São Paulo, Faculdade de Direito, São Paulo, 2014.

Rosenn, Keith S., Constitution of the Federative Republic of Brazil: October 5, 1988 (as Amended to September 15, 2015), Oxford, 2015.

Ruediger, MARCo A. \& Britto, Ângela, Criminalidade, sociedade e a prática da denúncia anônima de crimes, «Questio Juris» 3(1) (2007) <http://www.epublicacoes.uerj.br/index.php/quaestioiuris/article/view/3941/0>.

Ruediger, Marco A. \& Riccio, Vicente, Mídia, Estado e Sociedade Civil: a mobilização social da segurança pública pelo DisqueDenúncia (2009) <http://hdl.handle.net/10438/13273>.

SARmento, Daniel, Comentários ao art. $5^{\circ}$, $I V$ in J. J. G. CANOtilho, G. F. Mendes, I. W. SARLeT, L. L. StreCK (eds.), Comentários à Constituição do Brasil, Almedina/Saraiva, São Paulo, 2013.

SAVCHENKO, I I. \& GATSENKO, O Y., Analytical review of methods of providing internet anonymity, «Automatic Control and Computer Sciences» 49(8) (2016), pp. 696-700.

SCHAUER, Frederick, Held, Virginia, Hess, JOHN L. \& DWORKIN, RONALD, The Rights of M.A. Farber: An Exchange, published in New York Review of Books, 1978 $<$ http://www.nybooks.com/articles/1978/12/07/the-rights-of-mafarber-an-exchange/>.

SCHLESINGER, ARI, ChandRASEKHARAN, EshwAR, MASDEN, Christina A., BruckmAn, AMY S., ET AL., Situated anonymity: 
impacts of anonymity, ephemerality, and hyper-locality on social media (2017), pp. 6912-24.

SCHNEIER, BRUCE, Anonymity and the internet (2010)

$<$ https://www.schneier.com/blog/archives/2010/02/anonymity_and _t_3.html>, accessed 27.Aug.2017.

SCHNEIER, BRUCE \& MUdGE, Cryptanalysis of Microsoft's point-topoint tunneling protocol (PPTP) (1998), pp. 132-41.

Schneier, Bruce, Seidel, Kathleen \& Vijayakumar, Saranya, $A$ worldwide survey of encryption products (2016), pp. 1-24.

SCORDATO, MARIN, Distinction without a difference: a reappraisal of the doctrine of prior restraint, «North Carolina Law Review» 68 (1989), pp. 1-35.

SILER, ETHAN B., Yelping the way to a national statutory standard for unmasking internet anonymity, «Wake Forest Law Review» 51 (2016), pp. 189-210.

Silva, Marcos S., Site deve dizer quem são os críticos de Doria, decide juiz, published in Folha de São Paulo, 2017, p. B3.

Silva, OvíDio A. B. D., Comentários ao código de processo civil, vol. 13, RT, São Paulo, 2000.

SKOPEK, JefFREY M., Anonymity, the production of goods, and institutional design, «Fordham Law Review» 82(4) (2014), pp. 1751-809.

Solove, Daniel J., Conceptualizing privacy, «California Law Review» 90 (2002), pp. 1087-155.

Solove, Daniel J., Fourth Amendment pragmatism, «Boston College Law Review» 51 (2010), pp. 1511-38.

SOlOve, DANiEl J., "Nothing to hide" - The false tradeoff between privacy and security, Yale, New Haven, 2011.

Souza, CARlos A. P. DE, As cinco faces da proteção à liberdade de expressão no Marco Civil da Internet, in N. DE LUCCA, A. SIMÃo FILHO, C. R. P. DE LIMA (eds.), Direito \& Internet III: Marco Civil 
da Internet (Lei $n^{\circ}$ 12.965/2014), Quartier Latin, São Paulo, 2015, pp. 377-408.

STEIN, EDWARD, Queers anonymous: lesbians, gay men, free speech, and cyberspace, «Harvard Civil Rights-Civil Liberties Law Review» 38(1) (2003), pp. 159-213.

Streck, Lenio L., Comentários ao art. $5^{\circ}, X I V$, in J. J. G. CANotilho, G. F. Mendes, I. W. SARLET, L. L. STRECK (eds.), Comentários à Constituição do Brasil, Almedina/Saraiva, São Paulo, 2013.

Tan, Chenhao, Niculae, Vlad, Danescu-Niculescu-Mizil, CRISTIAN \& LEE, LILLIAN, Winning arguments: interaction dynamics and persuasion strategies in good-faith online discussions (2016), pp. 613-24.

TefFé, ChIARA A. S. DE, Responsabilidade civil e liberdade de expressão no Marco Civil da Internet: a responsabilidade civil dos provedores por danos decorrentes de conteúdo gerado por terceiros, «Revista de Direito Privado» 16(63) (2015), pp. 59-83.

TRIBUNAL SUPERIOR ElEITORAL, Eleições 2016: máquina fotográfica e celular são proibidos na cabina de votação (2016) $<$ http://www.tse.jus.br/imprensa/noticias-tse/2016/Julho/eleicoes2016-maquina-fotografica-e-celular-sao-proibidos-na-cabina-devotacao>, accessed 31.Jul.2017.

United NATIONS. Human Rights COUNCIL, Report of the Special Rapporteur on the promotion and protection of the right to freedom of opinion and expression, David Kaye (2015).

VAMIALIS, ANNA, Online defamation: confronting anonymity, «International Journal of Law and Information Technology» 21(1) (2013), pp. 31-65.

VAN DeR NAGEl, EMILY \& FRITH, JORDAN, Anonymity, pseudonymity, and the agency of online identity: Examining the social practices of r/Gonewild, «First Monday» 20(3) (2015).

VIANA, ULISSES S., Liberdade de expressão, comunicação e expressão do pensamento como princípios fundamentais do marco civil, in G. 
S. LeITE, R. LEMOS (eds.), Marco civil da internet, Atlas, São Paulo, 2014, pp. 127-47.

Wallace, Kathleen A., Anonymity, «Ethics and Information Technology» 1 (1999), pp. 23-35.

WEXLER, REBECCA, Warrant canaries and disclosure by design: the real threat to national security letter gag orders, "Yale Law Journal Forum» 124 (2015), pp. 158-79.

WinkLER, STEPHANIE \& ZEADALly, SHERALI, An analysis of tools for online anonymity, «International Journal of Pervasive Computing and Communications» 11(4) (2015), pp. 436-53.

WORTHAM, JENNA, New social app has juicy posts, all anonymous, published in New York TImes, 2014, p. A1 $<$ https://www.nytimes.com/2014/03/19/technology/new-social-apphas-juicy-posts-but-no-names.html>.

ZEDNER, LUCIA, Why blanket surveillance is no security blanket: data retention in the United Kingdom after the european data retention directive, in R. A. MILLER (ed.), Privacy and Power (A Transatlantic Dialogue in the Shadow of the NSA-Affair), Cambridge University Press, Cambridge, 2017, pp. 564-85.

ZHAO, SHANYANG, The internet and the transformation of the reality of everyday life: toward a new analytic stance in sociology, «Sociological Inquiry» 76(4) (2006), pp. 458-74.

Zuliani, ÊNio S., Art. $7^{\circ}$, in Comentários à lei de imprensa, RT, São Paulo, 2007, pp. 157-80.

The constitutional right to anonymity: free speech, disclosure and the devil, «The Yale Law Journal» 70 (1961), pp. 1084-128.

Bulletin! The "Internet" Is About to Get Smaller (2016) $<$ https://www.nytimes.com/2016/05/25/business/media/internet-tobe-lowercase-in-new-york-times-and-associated-press.html $>$. 